UDC 640.412:338.4

DOI: $10.31866 / 2616-7468.1 .2018 .147398$

\title{
THE MISSION OF THE GUIDE- ENTERTAINER IN THE DEVELOPMENT OF BUSINESS HOSPITALITY IN MODERN UKRAINE
}

Karyna Svidlo,

Doctor of Engineering Sciences, Kharkiv Institute of Trade and Economics

of Kyiv National University of Trade and Economics, Kharkiv, Ukraine, karinasvidlo@gmail.com https://orcid.org/0000-0002-0175-7756 (C) Свідло К. В., 2018

The purpose of the article is to analyse the mission of the guide-entertainer in the additional services development of a business hotel in Ukraine. The research methodology combines the systematization of information on the list of services of the guide-entertainer and comparison of qualification requirements for relevant professionals in France and Ukraine. The scientific novelty of the article is the identification of opportunities for the development of business hospitality in Ukraine by expanding the services of the hotel industry and increasing the number of high-qualified guides involved in providing services in the hotel industry. For effective implementation of the service, the guide-entertainer has conducted a simulation of the service process of providing services in the hotel, developed a functional block diagram of the service process. Conclusions. The article notes that due to the simplification of the visa regime in the countries of the European Union, international business tourism is becoming even more attractive for Ukraine. Currently there is a lack of significant limitations in the provision of services to the hotel industry in Ukraine, the absence of international hotels of international categories and small investments for the construction of new hospitality facilities, insufficient information and the lack of highly qualified personnel in the hotel industry.

Key words: guide-entertainer, business hospitality, business hotel, additional services.

\section{Actuality of problem}

It is noted that the mission of the guide-entertainer in the Ukrainian network of business hotels is to promote the development of business hospitality in Ukraine by providing high-quality services to corporate clients and foreign businessmen. We believe that the expansion of the services of the hotel industry and the increase in high-qualified guides attracted to the provision of services in the hotel industry will contribute to the development of the hotel industry in Ukraine.

The development of business hospitality in Ukraine happens due to simplified the visa regime for the countries of the European Union. In Ukraine, there are many business meetings, conferences, forums and congresses.

\section{Purpose and methods of research}

The purpose of the article is to analyse the mission of the guide-entertainer in the additional services development of a business hotel in Ukraine. The research methodology combines the systematization of information on the list of services of the guide-entertainer and comparison of qualification requirements for relevant professionals in France and Ukraine. 


\section{Results of research}

Therefore, corporate rest is another promising direction in the development of hotel and restaurant business. The directions of development of hotel facilities, which have gained success over the past few years are (Osnovni statystychni):

- strengthening the specialization of hotel and restaurant proposition;

- creation of international hotel chains;

- development of a network of small enterprises;

- $\quad$ using the latest computer technologies in the hotel industry.

Domestic and foreign tourists are attracted by considerable historical, cultural, natural and resource potential and the country's good geographical location. However, the analysis of many publications reveals problems that hinder the development of hotel and restaurant business and which could be solved with the help of effective state support (Kotler, Bouen, \& Meykenz, 2012; Levykin, \& Devon, 2015; Pysarevskyi, \& Seheda, 2015; Levykin, \& Devon, 2015; Spektor, 2015).

Among these problems:

- $\quad$ significant taxation;

- mandatory certification for hotel and restaurant services;

- imperfect accounting system of settlement in accommodation facilities;

- restrictions on the rendering of hotel industry services;

- absence of hotels of an international category and small investments for construction of new hospitality facilities;

- insufficient level of informatization;

- lack of qualified personnel in the hotel and restaurant industry.

Due to the simplification of the visa regime in the countries of the European Union, international business tourism is becoming even more attractive for Ukraine. That is why the innovative service of the guide-entertainer as an additional service at the business hotel makes the hotel more attractive and competitive by expanding the services of the hotel industry and increasing the qualified guides involved in providing services in the hotel industry.

Guide-entertainer is an individual guide who speaks foreign languages and can personally make excursions in any museum.

The guide-entertainer provides the following services:

- individual and group excursions;

- meeting of tourists at the airport and at the railway station;

- transfer;

- booking of tickets;

- accompaniment at business meetings, conferences;

- accompaniment at exhibitions and museums;

- car hire;

- oral and written translation.

Individual guides are usually sought by people who value their independence and want to get a personalized approach based on their own wishes for excursions and at the same time be confident in the high qualification of the guide and his responsibilities.

The guide-entertainer can both conduct sightseeing tours in various historical and cultural places, and has the official right to conduct excursions in museums. It is also important that in all the museums the guide-entertainer has the right to avoid queues, because the business person is always limited in time. Most of all, tourists who prefer 
individual tours win from the cooperation with the guide-entertainer. Because after ordering services of guide-entertainer they get a specialist who knows his subject well and at the same time can independently adjust the program of excursions, coordinating with the guide their individual wishes and priorities.

The profession of guide-entertainer is fundamentally new to Ukraine. It was devised in France. Regarding the normative and legal basis of the profession of guideentertainer, in France the profession of guide-entertainer is regulated by article L. 221-1 of the tourism codex, which obliges to hold lectures in museums and historical monuments, in the context of the service provided by the tourist operator and gives tourists the right to use the services of qualified specialists, holders of a professional card. Giving out this professional card is subject to the conditions set out in article L.222-1 of the tourism codex.

The terms for the issue of a professional card for a guide-entertainer in France are as follows:

license holders of professional guides;

holders of the national master's degree;

master's degree holders who have at least one year of professional experience gained over the past five years, in oral form.

Card holders of the professional guide-entertainer must have at least a foreign language with a European-wide base level C1, a regional language of France or a French sign language.

Regarding the status of the guide-entertainer, they participate in the socio-cultural animation of all tourist destinations.

Guide-entertainer can work independently or to be an employee (permanent, fixed-term, seasonal, independent or individual), belonging to various structures of hotel-tourist business.

In order to create a high-class active recreation for corporate clients and foreign investors, a number of innovations have been proposed for comfortable staying in business hotels of potential corporate clients and foreign business investors. The list of offered guide-entertainer services and their characteristics is shown in the table.

For effective implementation of the service, the guide-entertainer has conducted a simulation of the service process of providing services in the hotel, developed a functional block diagram of the service process.

Tabl. 1. List of services of the guide-entertainer

\begin{tabular}{|l|l|}
\hline \multicolumn{1}{|c|}{ Service } & \multicolumn{1}{c|}{ Characteristic } \\
\hline 1. Individual excursions & $\begin{array}{l}\text { Special tours of the hotel guide-entertainer to any } \\
\text { historical, cultural or entertainment attractions and } \\
\text { city establishments. Conducted for 3-7 people. }\end{array}$ \\
\hline 2. Group excursions & $\begin{array}{l}\text { Excursions from 4 people. As well as individual ones, } \\
\text { they are carried out according to a predefined route } \\
\text { and taking into account all wishes of the group. }\end{array}$ \\
\hline $\begin{array}{l}\text { 3. Accompanying at business meet- } \\
\text { ings, conferences }\end{array}$ & $\begin{array}{l}\text { A guide-entertainer can accompany domestic business } \\
\text { travellers and foreign tourists as an interpreter for } \\
\text { business meetings, conferences. }\end{array}$ \\
\hline
\end{tabular}


Tabl. 1.

\begin{tabular}{|l|l|}
\hline $\begin{array}{l}\text { 4. Accompanying at exhibitions and } \\
\text { museums }\end{array}$ & $\begin{array}{l}\text { Accompanying guide services for historical, cultural } \\
\text { and entertainment events. Advantages of guide- } \\
\text { entertainer accompanying are following: you don't } \\
\text { need services of museum guides and entrance without } \\
\text { queuing. }\end{array}$ \\
\hline 5. Car hire & $\begin{array}{l}\text { Guide-entertainer will help you quickly and efficiently } \\
\text { get a vehicle for your own residence. }\end{array}$ \\
\hline 6. Interpreting & $\begin{array}{l}\text { Guide-entertainer provides interpretation services for } \\
\text { foreign tourists. }\end{array}$ \\
\hline 7. Written translation & Written translation of documents for business tourists. \\
\hline 6. Booking tickets & $\begin{array}{l}\text { Booking of tickets for transport, booking of tickets for } \\
\text { theatre, cinema, for exhibitions, etc., ordering places } \\
\text { in a restaurant. }\end{array}$ \\
\hline 8. Transfer & $\begin{array}{l}\text { Meeting tourists at the airport and at the railway sta- } \\
\text { tion. Guests are transferred by car from the specified } \\
\text { location and delivered to and from the hotel. }\end{array}$ \\
\hline
\end{tabular}

\section{Conclusions and discussion of results}

The order of the guide-entertainer's service is provided by the reservation department at the time of the check-in or during advance booking of guest numbers. Guide guides run pre-recorded and in free mode. The service provider offers the basic package of guides and considers the possibility of providing services according to an individual guest order.

It is possible to pay for services at the time of order, if it concerns the ordering of guide-entertainer services from the standard package listed in the table above.

If the guides- entertainer service develops an individual package of services for the corporate clients group or a specific person, only after agreement with the financial and economic department in the hotel. This payment order will allow you to provide the flexibility to approach of the business hotel guests' requirements.

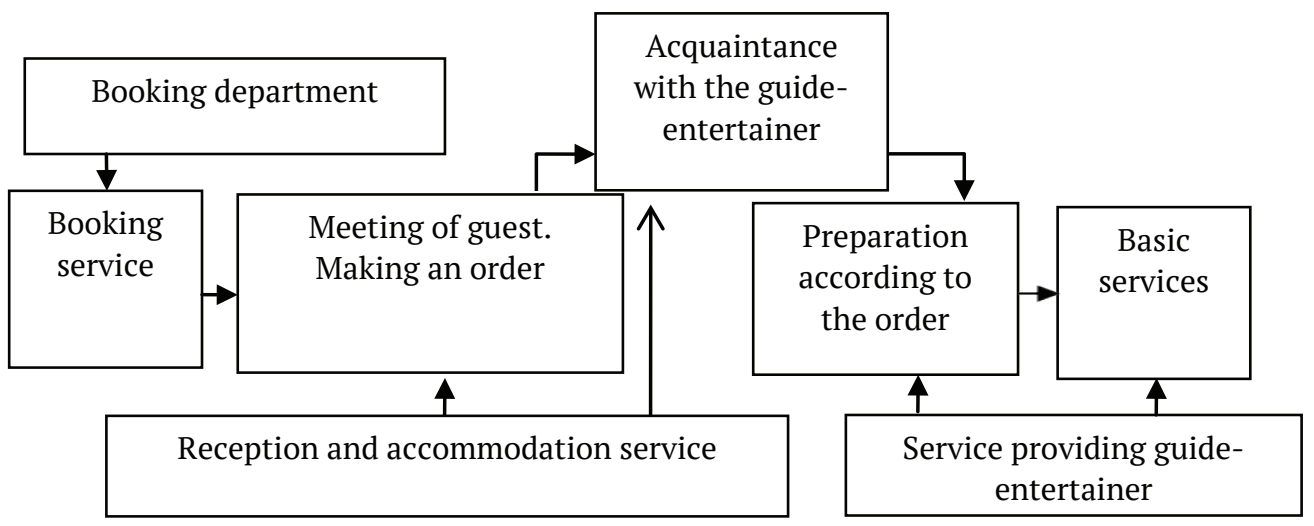

Fig. 1. Functional-structural scheme of service guide-entertainer

Thus, the guide-entertainer mission in the Ukrainian business hotel network is to promote the development of business hospitality in Ukraine by providing high- 
quality services to corporate clients and foreign businessmen. We believe that expanding the services of the hotel industry and increasing the quality of the guides involved in providing services in the hotel industry will contribute to the the hotel industry development in Ukraine.

\section{СПИСОК ПОСИЛАНЬ}

Котлер, Ф., Боуэн, Дж., \& Мейкенз, Дж. (2012). Маркетинг. Гостеприимство. Туризм. (В. Н. Егорова, пер.) (4-е изд.). Москва: ЮНИТИ.

Левикін, В.М, \& Девон, В.В. (2015). Аналіз, дослідження та розвиток конкурентоспроможності міні-готелів м. Києва. Science rise, 1/2 (6), 37-56.

Левикін, В.М., \& Девон, В.В. (2015). Дослідження ключових факторів, які впливають на прибуток міні-готелю у рамках проекту по вдосконаленню його діяльності. Технологічний аудит і резерви виробництва, 6 (22), 12-27.

Основні статистичні дані про діяльність готелів і ресторанів України (2017). Взято 3 http://www.sta.gov.ua.

Писаревський, I.M., \& Сегеда, I.В. (2015). Дослідження доходності підприємств готельного господарства. Технологічний аудит і резерви виробнищтва, 5 (24), 42-48.

Спектор, О. (2015) Економічна ефективність розширення асортименту додаткових послуг у готелі. Дев’яті економіко-правові дискусії, Матеріали конференції. Взято 3 http://www.spilnota.net.ua/ua/article/id-1428/.

\section{REFERENCES}

Kotler, F., Bouen, J., \& Meykenz, Dzh. (2012). Marketing. Gostepriimstvo. Turizm [Marketing. Hospitality. Tourism] (4nd ed). Moskow: YuNITI [in Russian].

Levykin, V.M, \& Devon, V.V. (2015). Analiz, doslidzhennia ta rozvytok konkurentospromozhnosti mini-hoteliv m. Kyieva [Analysis, research and development of the competitiveness of mini-hotels in Kiev]. Science rise, Scientific journal, 1/2 (6), 37-56 [in Ukrainian].

Levykin, V.M., \& Devon, V.V. (2015). Doslidzhennia kliuchovykh faktoriv, yaki vplyvaiut na prybutok mini-hoteliu u ramkakh proektu po vdoskonalenniu yoho diialnosti [Research of key factors that influence the profit of a mini-hotel within the project to improve its activities]. Technological audit and production reserves, 6(22), 12-27 [in Ukrainian].

Osnovni statystychni dani pro diialnist hoteliv i restoraniv Ukrainy. (2017) [Basic statistics on the activities of hotels and restaurants in Ukraine]. Retrieved from http://www.sta.gov. ua [in Ukrainian].

Pysarevskyi, I.M., \& Seheda, I.V. (2015). Doslidzhennia dokhodnosti pidpryiemstv hotelnoho hospodarstva [Investigation of the profitability of hotel enterprises]. Technological audit and production reserves, 5 (24), 42-48 [in Ukrainian].

Spektor, O. (2015). Ekonomichna efektyvnist rozshyrennia asortymentu dodatkovykh posluh $\mathrm{u}$ hoteli [Economic efficiency of expanding the range of additional services at the hotel]. In Deviati ekonomiko-pravovi dyskusii, Proceedings of the Conference Title. Retrieved from http://www.spilnota.net.ua/ua/article/id-1428/ [in Ukrainian]. 
УДК 640.412:338.4

Карина Свідло, доктор технічних наук, доцент, Харківський торговельно-економічний інститут Київського національного торговельноекономічного університету, Харків, Україна, karinasvidlo@gmail.com

https://orcid.org/0000-0002-0175-7756

\section{МІСІЯ ГІДА-КОНФЕРАНСЬЄ У РОЗВИТКУ ДІЛОВОЇ ГОСТИННОСТІ В СУЧАСНІЙ УКРАЇНI}

Мета дослідження - проаналізувати місію гіда-конферансьє у царині розвитку додаткових послуг ділового готелю в Україні. Методи дослідження поєднують систематизацію інформації щодо переліку послуг гіда-конферансьє, порівняння вимог до відповідних професіоналів у Франції та в Україні. Наукова новизна статті полягає у виявленні можливостей розвитку ділової гостинності в Україні за рахунок розширення послуг готельної індустрії та збільшення кількості гідів високої кваліфікації, залучених до надання послуг у готельній індустрії; проведенні моделювання сервісного процесу надання послуги в готелі і розробленні функціональної блок-схеми сервісного процесу послуги. Висновки. У статті наголошено, що нині у зв’язку зі спрощенням візового режиму до країн Європейського Союзу для України міжнародний діловий туризм стає ще привабливішим. Але на сьогодні в Україні відчутний брак або значні обмеження у наданні послуг готельної індустрії, відсутність готелів міжнародної категорії та малі обсяги інвестицій для будівництва нових закладів гостинності, недостатній ступінь інформатизації і відсутність кадрів достатньої кваліфікації у галузі готельного господарства.

Зазначено, що місія гіда-конферансьє в українській мережі ділових готелів полягає у сприянні розвитку ділової гостинності в Україні шляхом надання високоякісних послуг корпоративним клієнтам та іноземним бізнесменам. Вважаємо, що розширення послуг готельної індустрії та збільшення кількості гідів високої кваліфікації, залучених до надання послуг у готельній індустрії, сприятиме розвитку готельного господарства України.

Ключові слова: гід-конферансьє, ділова гостинність, діловий готель, додаткові послуги.

УДК 640.412:338.4

Карина Свидло,

доктор технических наук, доцент,

Харьковский торгово-экономический институт

Киевского национального торгово-

экономического университета,

Харьков, Украина,

karinasvidlo@gmail.com

https://orcid.org/0000-0002-0175-7756

\section{МИССИЯ ГИДА-КОНФЕРАНСЬЕ В РАЗВИТИИ ДЕЛОВОГО ГОСТЕПРИИМСТВА В СОВРЕМЕННОЙ УКРАИНЕ}

Цель исследования - проанализировать миссию гида-конферансье в области развития дополнительных услуг делового отеля в Украине. Методы исследования сочетают систематизацию информации о перечне услуг гида-конферансье и сравнение квалификационных требований к соответствующим профессионалам во Франции и в Украине. 
Научная новизна статьи заключается в выявлении возможностей развития делового гостеприимства в Украине за счет расширения услуг гостиничной индустрии и увеличения количества гидов высокой квалификации, привлеченных к оказанию услуг в гостиничной индустрии; моделировании сервисного процесса предоставления услуги гида-конферансье в отеле и разработке функциональной блок-схемы сервисного процесса услуги. Выводы. В статье отмечается, что в настоящее время в связи с упрощением визового режима в страны Европейского Союза для Украины международный деловой туризм становится еще более привлекательным. Однако в настоящее время в Украине ощущается недостаток или значительные ограничения в предоставлении услуг гостиничной индустрии, отсутствие отелей международной категории и малые объемы инвестиций для строительства новых заведений гостеприимства, недостаточная степень информатизации и отсутствие кадров высокой квалификации в области гостиничного хозяйства.

Отмечено, что миссия гида-конферансье в украинской сети деловых гостиниц заключается в содействии развитию делового гостеприимства в Украине путем предоставления высококачественных услуг корпоративным клиентам и иностранным бизнесменам. Считаем, что расширение услуг гостиничной индустрии и увеличение количества гидов высокой квалификации, привлеченных к оказанию услуг в гостиничной индустрии, будет способствовать развитию гостиничного хозяйства Украины.

Ключевые слова: гид-конферансье, деловое гостеприимство, деловой отель, дополнительные услуги. 